\title{
緑茶缶ドリンクの製造法
}

\author{
農林水産省茶業試験場 \\ *大和製年侏総合研究所 $・$ 清水研究室
}

原利男 - 久保田悦郎・堀田博 - 服部孝雄* - 野田忠行*

\section{Manufacturing Process of Canned Green Tea Drinks}

\author{
By Toshio Hara, Etsurō Kubota. Hiroshi Horita, \\ Takao HATTORI* and Tadayuki NODA* \\ National Research Institute of Tea \\ *Technical Research Laboratories, Daiwa Can Co. LTD. Shimizu Laboratories
}

\section{1 ま えがき}

茶の钲ドリンクについては，昭和56年にウーロン茶の 缶ドリンク（以下，ドリンクと略す）が南販され，60年 には大手の有名メーカーを含めて，100 社以上が市場に 参加して，采飲料の販売面でウーロン茶が非常に話題と なっている。

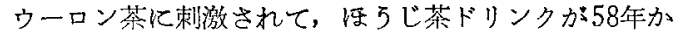
ら市販され，60年には緑茶ドリンクも発売された。緑茶 ドリンクは製造工程中の加熱によって起る，香味の劣化 が大きく，むだ多くの問題点が残されている。

そこで，緑茶ドリンクの製造工程中に晾る変色と， 香味の劣化を防止するため, 緑茶浸出液に L-アスコル ビン酸ナトリムウを添加することと, 窒素フローの巻締 注って品質を保持する方法を検討した。

この方法は，すでにメーカーで実用化されているが， 品質の保持勃果については全く報告されていないので, それを明確にするため本試験を行なった。

また，緑茶ドリンクは清涼领料の製造樭準で，缶に密 封した後, 年の中心部の温度 $85^{\circ} \mathrm{C}$ て 30 分加熱する万法, またはされれ同等以上の訤力を有する方法で殺菌するこ とが義務づけられている。通常, 安全性を考光て $115^{\circ} \mathrm{C}$ 〜 $120^{\circ} \mathrm{C}$ のレトルト殺菌を行なう。従って，急須でたし た茶に比較すると，緑茶ドリンクはどうしてる加熱によ る香味の低下はさけられないよらである。とくに，加熱 臭の生成が問題で，これを消去する方法として，緑茶に 䚾うじ茶を混合して，香気を強化する方法を検討した。 これらの結果をとりまとめて報告する。

\section{2 試 験 方 法}

\section{1 緑茶ドリンクの製造工程}

現在,メーカーで実施している缶ドリンクの製造法を
参考にして，図1に示した製造工程で本試験の緑茶ドリ ンクを作成した。

浸出は $80^{\circ} \mathrm{C}$ の純水（脱イオン水）で 3 分浸出した。メ 一カ一では浸出の際に $\mathrm{pH}$ 調整剤として，ごく微量（抽 剂に対し約 0.005\%）の炭酸水素ナトリウムを添加する 場合るある。これはレトルト殺菌中に $\mathrm{pH}$ が低下するの でそそれを補正するために行なら。

浸出した茶はステンレス製の茶こしでこして,さらに $5 \mu \mathrm{m}$ のフィルターペーパーでろ過した。そして，酸化 防止剂として約 $0.03 \%$ Lーアスコルビン酸ナトリウム

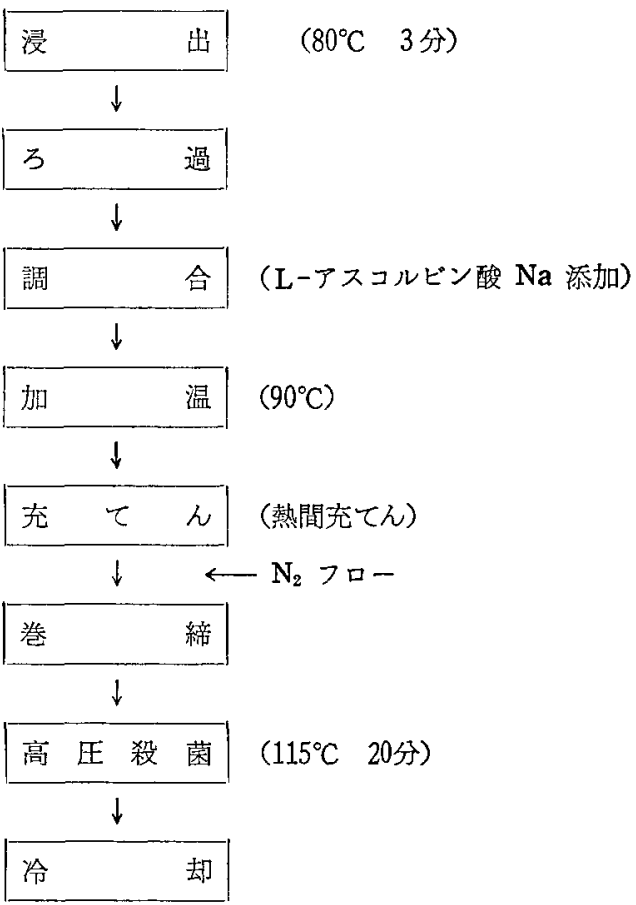

図 1 緑茶ドリンクの製造工程（実験室規模） 
を浸出液に添加した。Lーアスコルビン酸ては少しすっぱ くなり，炭酸水素ナトリウムで中和する必要があり， レーアスコルビン酸ナトリウムのほうが都合がよい。

つぎ，この浸出液を $90^{\circ} \mathrm{C}$ 亿加温して，澄い液を尔に 充てんし，出とふたの透き間に窒意字 $40 \mathrm{~m} l / \mathrm{min}$ の速 度で約20秒流して,ヘッドスペースの空気を窒素と惪換 して巻締を行なった。密封した缶は $115^{\circ} \mathrm{C} て 20$ 分レトル 卜殺菌した後に，水で命却して完成品とした。

\section{2 製造工程中における品質の劣化防止試験}

緑茶ドリンクの製造工程中に括ける品質の少化防止䳝 験は袁1に示したよ5に，1区は無処理漫出液を缶に充 てんして，レトルト殺菌した対照区。2区は無処理浸出 液を充てルして，窒素フロ一浩締をしたあの。3区は酸 化防止剂として L-アスコルビン酸ナトリウムを浸出液 に添加して，これを巻締，殺菌したもの。4区は3区の 浸出液を缶に充てんし，窒素フロー巻締をしたものであ 万。

また，この試験では浸出に使用する茶の最適量を調查 するため，抽剂（絋水 $3 l$ ) に対し，1.0\% (30g) と1.5 $\%(45 \mathrm{~g})$ の茶の浸出液の比較試験る行なった。供試茶 は1番茶期の中級煎茶を使用した。

製品の品質調查は，2人のパネルの合議制によって官 能検査て，色と香味を比較し，色差計によって製品の色 （透過光）を湘定した。

\section{3 緑茶ドリンク用原料の比較試験}

加熱による香味の低下が少ない原料学選択するため,

表 1 製造工程中に括ける品質の劣化防止試験の 区別と処理

\begin{tabular}{|c|c|}
\hline 区別 & 処 \\
\hline $1 区$ & 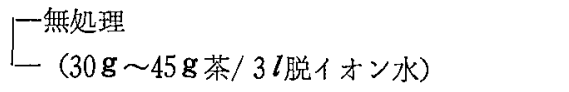 \\
\hline $2 区$ & $\begin{array}{l}\text { 一無炕理 } \\
-\mathrm{N}_{2} \text { フロー卷締 }\end{array}$ \\
\hline $3 区$ & $\begin{array}{c}\text { 一炭酸水素ナトリウム } 0.005 \% \text { (pH 調整) } \\
\text { 一 L-アスコルビン酸ナトリウム } 0.03 \% \\
\text { (酸化防止) }\end{array}$ \\
\hline 4 区 & $\begin{array}{l}\text {-3区浸出液 } \\
-\mathrm{N}_{2} \text { フロー巻締 }\end{array}$ \\
\hline
\end{tabular}

表 2 原料の比較試験の製造条件

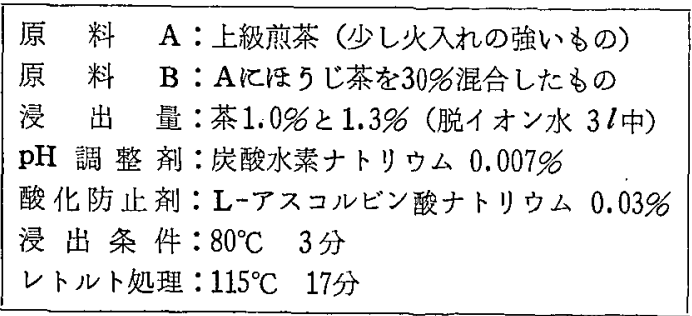

表 2 に示した原料の比較試験を行なった。区別は表 2 に 示したように，原料Aは少し火入れの強い上級朔茶， B はこれにほうじ茶を30\%混合したすのを网いた。漫出に 使用した茶の量は抽剂に対し，1.0\%と1.3\%で，製造条 件は表 2 と括りである。

製品の調查は，バキュウムキャンテスターによって年 内真空度, 製品の $\mathrm{pH}$, 色差計によって色（透過光）等 を測䇥した。また，当場職員25名をパネルとして，製品 のし好調查を，2点し好試験法によって行なった。

\section{3 試 験 結 果}

\section{1 製造工程中における品質の劣化防止試験}

緑茶ドリンクの製造工程中に拈ける品筫の步化防止試 験の結果は表 3，4のと少りて品る。

これによると，鉒品の色は Lーアスコルビン酸ナトリ りムを添加して，窒素つロ一卷締をした4区が鼠るよく，

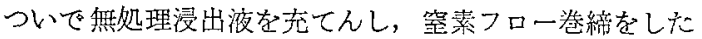
2区が良いよう認められた。従って，色の保持には Lアスコルビン酸ナトリウムの添加の効果るあるが，それ より窒素フロー巻締の効果が大きいように認められた。

表 3 浸出量 $1 \%$ 区の品質䛇查（官能検查）

\begin{tabular}{|c|c|c|}
\hline 区 & 色 & 昧 \\
\hline 1 区：無処理 & 少し褐変 & 加熱具強し \\
\hline 2 区: $\mathrm{N}_{2}$ フロー巻締 & p户良好 & 少し加悠臭 \\
\hline $3 区: \mathrm{ASA} \cdot \mathrm{Na}$ 添扣 & わずか炕褐变 & やや良好 \\
\hline $4 区:\left[\begin{array}{l}\mathrm{ASA} \cdot \mathrm{Na} \text { 添加 } \\
-\mathrm{N}_{2} \text { フロー淃締 }\end{array}\right.$ & 良好 & 良杍 \\
\hline
\end{tabular}

注: $\mathrm{ASA} \cdot \mathrm{Na}=\mathbf{L}-$ アスコル゙ン酸ナトリゥム 浸出量 $1 \%$ 区 $=$ 茶 $30 \mathrm{~g}$ を $3 l$ の脱イオン水で浸出

表 4 浸出量 $1.5 \%$ 区心品質調查（官能檢查）

\begin{tabular}{|c|c|c|}
\hline 区 & 色 & 味 \\
\hline 1 区：無処理 & かなり褐変 & 加熱臭強し \\
\hline 2 区: $\mathrm{N}_{2}$ フロー巻締 & やや良好 & 少し加熱臭 \\
\hline $3 区: \mathrm{ASA} \cdot \mathrm{Na}$ 添加 & 少し褐变 & や队良好 \\
\hline 4 区 : $\begin{array}{l}-\mathrm{ASA} \cdot \mathrm{Na} \text { 湑加 } \\
-\mathrm{N}_{2} \text { フロー港 締 }\end{array}$ & 良好 & 良好 \\
\hline
\end{tabular}

注：浸出量 $1.5 \%$ 区 $=$ 茶 $45 \mathrm{~g}$ を $3 l$ の脱イオン水て浸出 表 5 色の測定結颗（透過光）

\begin{tabular}{|c|c|c|c|c|}
\hline 区 & $\mathbf{L}$ & a & $b$ & $a / b$ \\
\hline $1 区$ : 拯好理 & 91.00 & -3.42 & 18.89 & 0.18 \\
\hline 2 区: $\mathrm{N}_{2}$ フロー & 91.73 & -3.52 & 17.35 & 0.20 \\
\hline $3 区: A S A \cdot N a$ & 91.83 & -4.17 & 21.49 & 0.19 \\
\hline $4 区: \begin{array}{l}\mathrm{ASA} \cdot \mathrm{Na} \\
-\mathrm{N}_{2} \text { フロー }\end{array}$ & 92.40 & -4.44 & 19.59 & 0.23 \\
\hline
\end{tabular}

注：浸出量 196 区 
第 64 号 $(19986)$

表 6 製品の調查結果（原料比較試験）

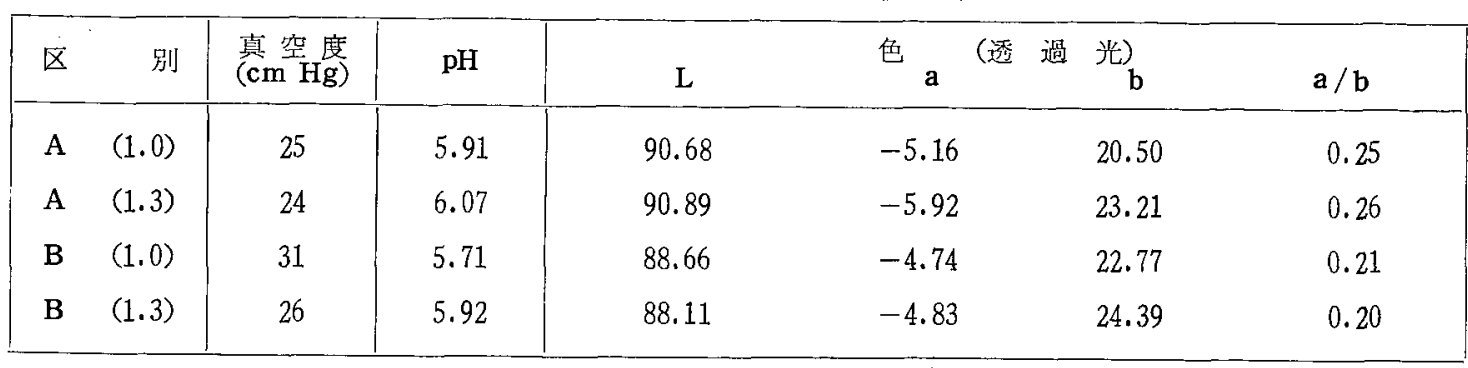

注：(1.0) は浸出量1.0\%，(1.3）は浸出量 $1.3 \%$ である。

また，香味については 4 区が最すよく，ついで 3 区が 良い上う認められた。従って，香味の保持には窒泰つ ロ一巻締の効果すあるが，Lーアスコルビン酸ナトリウム の添加の効果が大きいことが認められた。

なお，浸出量 $1.0 \%$ のものと $1.5 \%$ の製品の香味を比 較すると， $1.5 \%$ のもの洼5が少し香味が劣るよ5に 認められた。従って，浸出量 $1.5 \%$ では茶が少し多すぎ るょうに認められた。

つぎに，色差計による色の測定結果を表 5 に示した。 これによると，1区と2区，あるいは3区と4区のa 值 および $\mathrm{a} / \mathrm{b}$ 值に差が認められ, 窒素フロ一巻締の効果 は明らかになった。しかし，2区と4区の比較は，4区 に $\mathrm{pH}$ 調整剂が添加してあるため, 色の性質がかなり異 なるので，その比較は困難であった。

\section{2 緑茶ドリンク用原料の比較試験}

緑茶ドリンクは，レトルト殺菌中の加熱汇よる香味の 低下はどらしてもさけられないので，それに適した原料 在選抧する手初めとして，上級煎茶に浪らじ茶索混命し て香気を強化する方法を検討した。

試作した製品の分析結果は表6のと挔りで，畋内点空 度は24〜31 cm でかりの真空度になっていた。製品の $\mathrm{pH}$ は 5.7〜6.0であった。製品の色は活5じ茶を淈酉 したものの恬5が，L值（明るさ）と、值（一）が少し 隇少し，煎茶の色としては少し劣ることが認められた。

つぎに，25名のパネルで製品のし好調查を行った結果 は表 7 のと战りで，浸出量 $1.0 \%$ と $1.3 \%$ ののには差 は認めら机かった。試料 $\mathrm{A}$ と $\mathrm{B}$ とは $5 \%$ 有意差でB

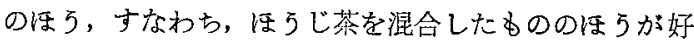

表 7 製品のし好調查（原料比較試験）

\begin{tabular}{lccc}
\hline 試 & 料 & $\mathrm{A}(1.0)$ & $\mathrm{A}(1.3)$ \\
\hline 好んだ人数 & 13名 & 12名 \\
\hline & & & \\
\hline 試 & 料 & $\mathrm{A}(1.0)$ & $\mathrm{B}(1.0)$ \\
\hline 好んだ人数 & 7 名 & 18 名* \\
\hline
\end{tabular}

注 : *5\%の危険率で有意差あり。
まれていだ。

\section{4 考察}

以上曰の試験結果から，緑茶ドリンクの製造は，酸化防 止剂として浸出液に Lーアスコルビン酸ナトリムムを添 加し，咥素フローの卷縍を行ない，容器内の酸索をでき る限り少なくすれば，レトルト殺菌中に起る色と香味の 劣化をかなり防止できることが明らかになった。この方 法はメ一カーですで笑施されているし，緑茶漫出液の 褐変防止に L-アスコルビン酸の添加の効果がかなり誋 められることは坂本が報告している。

しかしこの上5にして製造した緑茶ドリンクも，レ トルト殺菌中の加熱にょる香味の低下，とくに加熱臭の 生成がかなり認められ，急須で出した緑茶と比較すると， 品質的にはかなり劣る。つまり, 緑茶ドリンクは清涼飲 料の製遗基準と安全性からレトルト殺菌在少略できない ので，現在の製造技術で㴔須で出した緑茶の香味をそ のま保持することはでさない。

そこで，緑茶ドリンクの製造中绕生成する加熱臭を消 去する方法として，煎茶に漂うじ茶を混合して，香気を 強化する力法を㭘討し，これによってある程度は香味改 善のできることを明らかにした。今後，緑茶ドリンクと しては，従来からの念須で出した緑茶の香味を追究する のではなく，加熱によっても香味の劣化が目立たない原 料を選択し，香味のよい緑茶ドリンクを開発する必要が あると考点る。

また，缶ドリンクの浸出液は通常急須で出した茶より 濃度かかなりうすい。すなわち，通常急須で出す場合に は $10 \mathrm{~g}$ の茶を約 $450 \mathrm{~m} l$ の湯で浸出する。缶ドリンクは $10 \mathrm{~g}$ の茶を $1 l$ の湯で浸出する。これは，缶ドリンクの

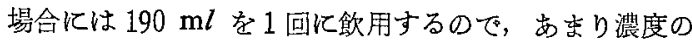
こいものは不向きとなる。

さらに，レトルト殺菌中に生成する加熱臭は，漂度の こい湫らか強く感ずる。従って, 浸出量は抽剤に対し約 $1 \%$ 茶が最適と認められた。

\section{5 要約}

緑茶ドリンクの製造中に㧍る変色と香味の少化を防 
止するため，浸出液に L-アスコルビン酸ナトリウムを 添加することと, 蓺間充てんの際, 缶とらたの間に窒素 を流した後，巻締をする方法の品質保持勃果を検討し た。

その結果, 緑茶ドリンクの装造には，浸出液に L-ア スコルビン酸ナトリウムを添加することと，熱閔充てん の際に窒素を流して，ヘッドスペースの酸素量を少なく して、淃締を行ならことが必要であった。 また，緑茶ドリンクに使用する茶の量は抽郕に対して 約 1 \%かが最適であることを認めた。

\section{6 引用文 献}

1）日本食品衛生拹会：食品，添加物等の規格基準（改 正), 清涼飲料水等, p. 42 (1982).

2）坂本 裕：䒩業試験場研究報告, No. $6,48 \sim 51$ (1970).

\section{Summary}

The effects of the addition of L-ascorbic acid to green tea infusion and the exchange of headspace volume with nitrogen gas before sealing process were investigated to prevent the deterioation of the infusion color and flavor during the pasterization of canned green tea drink.

From the results of the investigation, it was demonstrated that those treatments played an important role in the keeping of the quality of canned green tea drink during the pasterization.

A suitable concentration of green tea infusion for the canned green tea drink was obtained by using about one percent of green tea to a weight of hot water.

(Feb. 28, 1986) 